Dmytro V. Stefanyshyn, D. S. (Engineering), Lead researcher ${ }^{1}$, Professor of Department of Hydrotechnical Construction and Hydraulic ${ }^{2}$

ORCID ID: 0000-0002-7620-1613 e-mail: d.v.stefanyshyn@nuwm.edu.ua

${ }^{1}$ Institute of Telecommunications and Global Information Space of the NASU, Kyiv, Ukraine

${ }^{2}$ National University of Water and Environmental Engineering (NUWEE), Rivne, Ukraine

\title{
FEASIBILITY ANALYSIS OF CONSTRUCTION OF NEW HYDROPOWER PLANTS IN UKRAINE TAKING INTO ACCOUNT THE RISK OF UNUSED POSSIBILITIES
}

\begin{abstract}
The article presents results of feasibility analysis of construction of new hydropower plants in Ukraine according to the Hydropower development program for the period till 2026, which was approved by our Government in 2016. In particular, there are analyzed perspective plans for building the Kakhovka hydropower plant \#2 and six new hydropower plants on the river Dniester, as well as developing small hydropower in the country. The feasibility analysis is based on pairwise comparison of alternatives by the criterion of minimum aggregate risk taking into account the risk of unused opportunities. Components of aggregate risks of alternatives are estimated in dimensionless units for water-energy and operability characteristics and costs of commissioning of new hydro aggregates.

Keywords: aggregate risk; alternative; decision-making; feasibility analysis; hydropower; hydropower plants; optimization; pairwise comparison; renewable energy; risk of unused possibilities
\end{abstract}

\section{Introduction}

In connection with the accelerated development of renewable energy in our country $[1,2]$, especially solar and wind [3-6], being observed in the last decade (Table 1), a number of difficult issues has appeared relating to sustainable and reliable functioning the national combined energy system (CES) in the conditions of a significant deficit of regulating capacities of large hydropower plants (HPPs) and pumped-storage hydropower plants (PSHPPs) [7-9].

(C) D.V. Stefanyshyn, 2019 
Table 1 - Renewable energy in Ukraine $(\mathrm{MW})^{1}[3-6]$

\begin{tabular}{|c|c|c|c|c|c|c|c|c|c|c|c|}
\hline \multirow{2}{*}{$\begin{array}{l}\text { Renewable } \\
\text { Energy }\end{array}$} & \multicolumn{11}{|c|}{ Years } \\
\hline & 2009 & 2010 & 2011 & 2012 & 2013 & 2014 & 2015 & 2016 & 2017 & 2018 & $2019^{3}$ \\
\hline Wind $^{2}$ & 84 & 87 & 151 & 194 & 334 & 426 & 426 & 438 & 465 & 533 & 706 \\
\hline Solar $^{2}$ & - & 3 & 191 & 326 & 616 & 411 & 432 & 531 & 742 & 1388 & 2072 \\
\hline $\begin{array}{l}\text { Household } \\
\text { solar }\end{array}$ & - & - & - & - & - & 0.1 & 2 & 17 & 51 & 157 & 157 \\
\hline $\begin{array}{l}\text { Small } \\
\text { hydropower }\end{array}$ & 66 & 68 & 71 & 73 & 75 & 80 & 87 & 90 & 95 & 99 & 99 \\
\hline Biomass & - & - & - & 6 & 17 & 35 & 35 & 39 & 39 & 52 & 52 \\
\hline Biogas & - & - & - & - & 7 & 14 & 17 & 20 & 34 & 46 & 51 \\
\hline New & - & 8 & 255 & 186 & 450 & -83 & 33 & 136 & 291 & 849 & 862 \\
\hline Total & 150 & 158 & 413 & 599 & 1049 & 966 & 999 & 1135 & 1426 & 2275 & 3137 \\
\hline
\end{tabular}

${ }^{1}$ Without large hydropower generation

${ }^{2}$ Without power generation in the Autonomous Republic of Crimea and in the occupied territory of Donbas (in total, Russia has arrogated 633.7 MW of renewable energy of Ukraine)

${ }^{3}$ According to data for the first quarter of 2019

The role of manoeuvre power sources in the combined energy systems is best fulfilled by HPPs and PSHPPs. For example, starting hydropower units from a stopped position in a turbine mode with synchronization and a complete set of power is only 1-2 minutes; while at idling speed is $15-30$ seconds. Changing the power of the hydro unit or its stop needs only a few seconds [9]. In conditions of significant unevenness of daily power load schedules in the combined energy systems, it is the HPPs and PSHPPs, which have the highest manoeuvrability and the largest regulatory range (Table 2), in general, can best provide a stable, efficient and reliable operation of the national energy system.

Table 2 - Comparative characteristics of manoeuvrable qualities of main types of power plants [9]

\begin{tabular}{|c|c|c|c|c|}
\hline \multirow{2}{*}{ Types of power plants } & \multirow{2}{*}{$\begin{array}{l}\text { Technical minimum load, } \\
\% \text { (the ratio of minimum } \\
\text { permissible power to the } \\
\text { installed power) }\end{array}$} & \multirow{2}{*}{$\begin{array}{l}\text { Regulation } \\
\text { range, } \%\end{array}$} & \multicolumn{2}{|c|}{$\begin{array}{l}\text { Time to set the full } \\
\text { power, min }\end{array}$} \\
\hline & & & $\begin{array}{c}\text { After } \\
\text { stopping }\end{array}$ & $\begin{array}{l}\text { From the } \\
\text { "hot" state }\end{array}$ \\
\hline Nuclear & $85-90$ & $10-15$ & $390-660$ & 60 \\
\hline Thermal (coal, fuel oil) & $70-80$ & $20-30$ & $90-180$ & $20-50$ \\
\hline Gas turbines & 0 & 100 & $15-30$ & 0.5 \\
\hline Hydraulic & 0 & 100 & $1-2$ & $0.25-0.5$ \\
\hline Pumped-storage & 0 & 200 & $1-2$ & $0.25-0.5$ \\
\hline
\end{tabular}

It is believed that for the stable and reliable operation of the CES of Ukraine, the share of manoeuvrable capacities in its overall electricity balance should be about $15-20 \%$ [7-9]. At present, the domestic hydropower is capable of reliably providing only about $8-9 \%$ of such regulating capacities. As a result, the main regulatory role in the CES of our country is mainly performed by thermal power plants (TPPs) [7]. However, utilization of capacities of the TPPs for adjusting load schedules is uncharacteristic, economically inexpedient and even dangerous for the specified type of power generation. The work of the TPP's equipment with a change in load, frequent systematic shutdowns and start-ups of units, leads to decreasing in their efficiency, fuel overconsumption, accelerated aging of equipment, increasing 
probability of failures and cost price of electric power. In particular, it is associated with increasing environmental pollution.

Therefore, the decisions on further increase of hydro generating capacity in the country, laid out in the Hydropower development Program for the period till 2026 [7], at first glance, are quite rational. Ukraine requires additional high-manoeuvrability and regulatory electro generation capacities, including because of the development of renewable solar and wind energy, which is characterized by a high degree of dependence on climatic conditions and instability of electricity generation $[1,2,7-9]$.

\section{Some general remarks concerning current state of hydropower in Ukraine}

The main functions of domestic hydropower are the regulation of frequency and load schedules in the CES and the formation of an emergency power reserve providing the technological energy safety of the country $[8,9]$.

Some quantitative characteristics of hydropower development in Ukraine from 2010 till 2018 are given in Table 3. During this period, in the country there have been commissioned three hydro aggregates on the Dniester PSHPP with total capacity of $972 \mathrm{MW}$ in turbine mode (1263 MW in pumping mode) and $31 \mathrm{MW}$ of small hydropower.

Table 3 - Hydropower in Ukraine (MW) (according to data from [3-6])

\begin{tabular}{|c|c|c|c|c|c|c|c|c|c|}
\hline \multirow{2}{*}{$\begin{array}{l}\text { Power } \\
\text { plants }\end{array}$} & \multicolumn{9}{|c|}{ Years } \\
\hline & 2010 & 2011 & 2012 & 2013 & 2014 & 2015 & 2016 & 2017 & 2018 \\
\hline $\begin{array}{l}\text { Large } \\
\text { hydropower }\end{array}$ & 5400.2 & 5400.2 & 5400.2 & 5724.2 & 5724.2 & 6048.2 & 6048.2 & 6048.2 & 6048.2 \\
\hline $\begin{array}{l}\text { Small } \\
\text { hydropower }\end{array}$ & 68 & 71 & 73 & 75 & 80 & 87 & 90 & 95 & 99 \\
\hline $\begin{array}{l}\text { Total } \\
\text { hydropower }\end{array}$ & 5468.2 & 5471.2 & 5473.2 & 5799.2 & 5804.2 & 6135.2 & 6138.2 & 6143.2 & 6147.2 \\
\hline $\begin{array}{l}\text { Share, \%, of } \\
\text { small hydro } \\
\text { in total } \\
\text { hydropower }\end{array}$ & 1.24 & 1.30 & 1.33 & 1.29 & 1.38 & 1.42 & 1.47 & 1.55 & 1.61 \\
\hline $\begin{array}{l}\text { Share, \%, of } \\
\text { hydropower } \\
\text { in total } \\
\text { renewable } \\
\text { energy } 1\end{array}$ & 97.19 & 92.98 & 90.14 & 84.68 & 85.73 & 86.00 & 84.39 & 81.16 & 72.99 \\
\hline $\begin{array}{l}\text { Share, \%, of } \\
\text { small hydro } \\
\text { plants in } \\
\text { renewable } \\
\text { energy }^{2}\end{array}$ & 43.04 & 17.19 & 12.19 & 7.15 & 8.28 & 8.71 & 7.93 & 6.66 & 4.35 \\
\hline
\end{tabular}

${ }^{1}$ With large hydropower

${ }^{2}$ Without large hydropower

In general, the share of hydropower in the overall balance of renewable energy in Ukraine from 2009 till the first quarter of 2019 decreased from $97.33 \%$ to $66.21 \%$. Accordingly, in this period the potential for more efficient regulation of the load schedule in the CES of the country, by means of highly manoeuvrable hydropower facilities, has decreased too. It should also be mentioned that the small hydropower 
industry that has been developing in the country in recent years (Table 3) does not have sufficient regulatory capacity compared to large hydropower. Moreover, the work of small hydropower plants according to the "green tariff" in the CES of Ukraine, taking into account the climate, topography, and hydrological characteristics of domestic small rivers [10], can be considered more in the context of renewable energy that needs regulation. The only thing that can be calmed in this situation is that the share of small hydropower in the balance of hydropower facilities in the country is negligible. There is also a tendency for a significant reduction of the share of small hydropower in the structure of non-traditional renewable energy (see Table 3, without large hydropower). From 2009 till the first quarter of 2019 it has fallen from $44 \%$ to $3.16 \%$. At present, the power of solar plants in households (see Table 1) in the country is already twice the installed capacity of small hydropower. Household solar, along with bioenergy (biomass and biogas), can be considered as a more acceptable "green" alternative to small hydropower, given that, in general, small hydropower in Ukraine can not be considered as environmentally friendly, including in comparison with the domestic large hydropower [10-12].

As for our large hydropower, one of its important features is a significant proportion of hydro-accumulation in installed capacity. In turbine mode, this share already makes up almost 25\% (1508.5 MW). Taking into account the pumping storage mode $(2016 \mathrm{MW})$, the overall regulation range in the CES thanks to the large hydropower currently reaches 8064.2 MW. Considering the world tendencies of hydropower development with gradual accent on hydro-accumulation, and limited reserves of hydropower potential of rivers in the country [13, 14], an increase in the share of hydro-accumulation can be considered as a positive aspect of the further development of hydropower in the country.

\section{Some general remarks concerning the Hydropower development program for the period till $\mathbf{2 0 2 6}$}

The Hydropower development program for the period till 2026 [7] was approved by our Government in 2016. This Program has envisaged achieving an ambitious goal, namely, increasing the share of hydrogeneration in the overall electricity balance of the country from the current $8-9 \%$ up to $15 \%$.

Although the achievement of the hydropower share of $15 \%$ in the total balance of the CES due to the implementation of the Program [7] is quite questionable, in any case an increase in highly manoeuvrable regulatory capacity of hydropower in the national energy system will have a positive effect.

In particular, according to the Program, the following actions are foreseen to provide (See also Table 4):

- completion of construction the Dniester and the Tashlyk pumped-storage hydropower plants (PSHPP), the construction of the Kaniv PSHPP;

- the second stage of reconstruction of the HPPs of the Dniprovsky and Dnistrovsky cascades (in general, reconstruction of 76 hydro units is envisaged);

- construction of the Kakhovka HPP\#2 to expand the Kakhovka HPP on the Dnipro River and the construction of six new hydropower plants on the Dniester River (the so-called Upper Dnistrovskyi cascade of HPPs);

- as well as rehabilitation and construction numerous small hydropower plants (with the participation of private investors and state support for their activities through the "green tariff"). 
Table 4 - The expected outcomes of the Program [7]

\begin{tabular}{|c|c|c|c|c|}
\hline \multicolumn{2}{|c|}{ Power plants } & $\begin{array}{c}\text { Installed capacity } \\
N, \mathrm{MW}\end{array}$ & $\begin{array}{c}\text { Power generation } \\
E, \mathrm{MW} \cdot \mathrm{h}\end{array}$ & $\begin{array}{c}\text { Cost } C, 10^{9}, \\
\text { hryvnias }\end{array}$ \\
\hline \multirow{2}{*}{ Dniester PSHPP } & the second stage & $324\left(421^{\mathrm{I}}\right)$ & $388.5\left(515.5^{\mathrm{II}}\right)$ & 2.8 \\
\hline & the third stage & $972\left(1263^{\mathrm{I}}\right)$ & $1165.5\left(1546.5^{\mathrm{II}}\right)$ & 8.4 \\
\hline \multicolumn{2}{|l|}{ Tashlyk PSHPP } & $604\left(861^{\mathrm{I}}\right)$ & $582\left(785^{\mathrm{II}}\right)$ & 14.9 \\
\hline \multicolumn{2}{|l|}{ Kaniv PSHPP } & $1000\left(1120^{\mathrm{I}}\right)$ & $1017\left(1153^{\mathrm{II}}\right)$ & $40.5^{\mathrm{III}}$ \\
\hline \multicolumn{2}{|c|}{ Reconstruction of existing HPPs } & 307 & 330 & 22.33 \\
\hline \multicolumn{2}{|c|}{ Kakhovka HPP\#2 } & 250 & 44 & $13.47^{\mathrm{IV}}$ \\
\hline \multicolumn{2}{|c|}{ Upper Dnistrovskyi cascade of HPPs } & 390 & 710 & $31.9^{\mathrm{V}}$ \\
\hline \multicolumn{2}{|c|}{ Small hydropower VI } & 88 & 120 & - \\
\hline \multicolumn{2}{|l|}{ Total } & $3935\left(3665^{\mathrm{I}}\right)$ & $4387\left(4000^{\mathrm{II}}\right)$ & 134.3 \\
\hline $\begin{array}{l}\text { IPumped-storage } \mathrm{n} \\
\text { II Energy consumpt } \\
\text { III USD } 1.5 \text { billion } \\
\text { IV } 0.42 \text { billion Euro } \\
\text { V } 1.1 \text { billion Euros } \\
\text { VI Priote }\end{array}$ & $\begin{array}{l}\text { in pumping mod } \\
\text { rices for January } \\
\text { prices for Janua } \\
\text { prices for January }\end{array}$ & $\begin{array}{l}013 \\
2013 \\
014\end{array}$ & & \\
\hline
\end{tabular}

Provided the Program [7] is fully implemented, the installed hydrogeneration capacity in the national energy system will increase by $39 \%$. The share of hydroaccumulation in the overall balance of hydrogeneration in the country will also increase and reach $43 \%$. It can be concluded that the development of hydroaccumulation in the near future is a priority objective of the Program [7].

In particular, the Program [7] states that according to the National Renewable Energy Action Plan [1, 2], the total installed capacity of wind power plants and solar power stations, which are non-manoeuvrable power generating capacity, is expected to increase almost fivefold. It is also indicated that an increase in installed power of objects of power engineering using these renewable energy sources should be carried out within the limits that are technically feasible to ensure the reliability of the functioning of the CES of Ukraine. Finally, it is recognized that the use of pumpedstorage hydropower plants is a universal mechanism for solving the problems that exist in the CES of Ukraine.

However, the Program also provides for the modernization and reconstruction of existing hydropower plants and the construction of new HPPs. At the same time, with the total capacity of additional hydrogeneration at large HPPs of about $947 \mathrm{MW}$, which is more than three times less than the expected new hydrogeneration capacity at the PSHPP (2900 MW), the total costs for commissioning of additional hydrogeneration at the HPPs will be even slightly higher than the costs concerning the PSHPPs. Small hydropower, which is financed by private investors, practically does not change this negative relation between hydrogeneration at the HPPs and the PSHPPs.

\section{Topicality, general objective and particularities of the research}

In practice, not only cost indicators and ratio of expected results determine feasibility of projects. Projects may be effective but not feasible. The effectiveness of any project can be stimulated by various kinds of preferences, for example, in the form of a "green tariff" for produced electricity, etc. However, a feasible project does not necessarily have to be absolutely effective too. For example, the Program's [7] project for the reconstruction of existing hydropower plants of the Dnipro and Dniester cascades may be considered quite feasible. Provided it is needed, various 
alternatives to its implementation may be analysed to find among them a more efficient (optimal, etc.) one.

It is known that hydropower projects, like any other projects, may be burdened with various risks, including the risks of unused (lost, etc.) possibilities (or opportunities, etc.). The latter risks should also be taken into account when comparing alternatives and making decisions. It is also known that traditional hydropower can have a significant impact on the environment $[15,16]$. Besides of the expected positive effects, unexpected negative socio-environmental and economic effects may occur, affecting other perspective fields of human activity, limiting possibilities for other natural resources users. Taking into account even the most significant socio-ecological and socio-economic effects is a complicated task of analyzing and comparing alternatives. It is quite difficult to get rid of the influence of various subjective conclusions while solving similar tasks. However, the task could be simplified if, at the final stage of decision-making, the best alternatives are compared in their spheres, fields, etc. These chosen alternatives may be considered more feasible than others.

In the research, a method of decision-making was used on the basis of a pairwise comparison of alternatives taking into account the risk of unused possibilities (opportunities). The fundamentals of the method are given in [17]. The method has already been used to solve several tasks related to development of the national hydropower. The first task concerned selecting the optimal variant for the development of the Dnipro HPPs cascade taking into account the risk. The task had been considered in 2010 [18] before approving the Program [7]. There had been established the feasibility of construction of the Kaniv PSP in comparison with the construction of the Kakhovka HPP\#2. As the next feasible option of the cascade development it was determined the construction of the Kakhovka HPP\#2 with three or four additional units and total installed capacity of 168-224 MW. The second task concerned grounding of an optimal scenario for setting of new hydrogeneration capacities at PSHPPs in Ukraine in accordance with the Program [7]. In particular, it was concluded the feasibility of the commissioning at first of the fourth aggregate of the Dniester PSHPP with the subsequent construction of the Kaniv PSHPP in comparison with other possible alternatives [19].

The purpose of this article is to ground the feasibility of building new hydropower plants in Ukraine in accordance with the Program [7] taking into account the risk of unused possibilities. Among the possible options is the construction of the Kakhovka HPP\#2, the Upperdnistrovsky cascade of the HPPs and the further development of small hydropower (See Table 4). The problem is solved on the basis of a pairwise comparison of alternatives according to the method [17]. The peculiarity of the solution of the problem is that the project of the second stage of the reconstruction of existing hydroelectric plants of the Dnipro and Dniester cascades in the Program [7] is accepted as a "zero" alternative.

\section{Formalization of the research: Risks of alternatives and decision making}

According to the method presented in [17], the aggregate (or total) risk of each of alternatives is determined in the form of a linear combination of possible costs or other negative effects and results $l$ associated with the corresponding decision, and the expected positive effects or results (benefits, gains, achievements, advantages) $g$ that can be obtained in the case of an alternative solution. 
The task of multicriteria optimization on a countable set of admissible alternatives $\mathbf{A}=\left\{a_{i}\right\}, i=\overline{1, n}$, while their pairwise comparison, is reduced to the next optimization problem:

$$
d_{o p t}=\left\{a_{i, o p t} \mid a_{i, o p t} \in \mathbf{A} \wedge r_{i, o p t}=\min \left(r_{i, j}, r_{j, i}\right) \forall\left(a_{i}, a_{j}\right)\right\}, i, j=\overline{0, n}, i \neq j,
$$

where $r_{i, j}, r_{j, i}$ are aggregate risks, respectively, for an alternative $a_{i}$ when comparing it with $a_{j}$, and $a_{j}$ comparing with $a_{i}: r_{i, j}=l_{i}+g_{j}, r_{j, i}=l_{j}+g_{i}$, where $l_{i}, l_{j}$ and $g_{i}, g_{j}$ are the values of the correspondingly normalized convolutions of criteria, which are subject to minimization or maximization, of the alternatives $a_{i}$ and $a_{j}$ presented as own (or systemic) risks and risks of unused possibilities of the alternatives $a_{i}, a_{j}$.

In general, various positive and negative effects or results may have different units of measurement. Therefore, the quantitative assessment of the relevant components of aggregate risk is carried out in dimensionless units (scores) based on a universal $\log$ scale (see also [17-19]). Then, the score of some value $y_{k}$ of the corresponding characteristic will be like that:

$$
r\left(y_{k}\right)=\mu_{k} \cdot \lg y_{k}+y_{k, 0},
$$

where $\mu_{k}$ is module, $y_{k, 0}$ is zero point on the integral log scale length $L$ (let $L$ be equal to 10) for characteristic $y_{k}$ :

$$
\mu_{k}=\frac{L}{\lg y_{k, \text { max }}-\lg y_{k, \text { min }}}, y_{k, 0}=-\mu_{k} \lg y_{k, \text { min }}
$$

where $y_{k, \max }, y_{k, \min }$ are maximum and minimum values of $y_{k}$.

If $y_{k, \text { min }}=0$ it will be counted that $y_{k, 0}=0, \mu_{k}=\frac{L}{\lg y_{k, \max }}, r(0)=0$.

Further, the components of aggregate risks (systemic risks $l$ and risks of unused possibilities $g$ ) of each alternative $a_{i}$ in comparison with $a_{j}$ are represented by the sums of scores of the corresponding characteristics, namely:

$$
l_{i}=\sum_{k=1} l_{k, i}, g_{j}=\sum_{k=1} g_{k, j} .
$$

After the formation of the assessments of risk (4), the aggregate risks of alternatives are determined in the form of linear combinations $r_{i, j}=l_{i}+g_{j}, r_{j, i}=l_{j}+g_{i}$. Pairwise comparisons of alternatives with choosing better one among them are carried out according to the rule (1). 


\section{Solving the problem and results obtained}

While researching there were considered and pairwise compared eight alternatives. They were ordered and numbered according to increasing installed capacity. These are alternatives $a_{0} \div a_{7}$ (See their characteristics in Table 5):

- $a_{0}$ is the second stage of reconstruction of the HPPs of the Dniprovsky and Dnistrovsky cascades (the "zero" alternative);

- $a_{1}$ is the second stage of reconstruction of the HPPs of the Dniprovsky and Dnistrovsky cascades, and also the further development of small hydropower;

$-a_{2}$ is the second stage of reconstruction of the HPPs of the Dniprovsky and Dnistrovsky cascades, and also the construction of the Kakhovka HPP\#2;

$-a_{3}$ is the second stage of reconstruction of the HPPs of the Dniprovsky and Dnistrovsky cascades, the construction of the Kakhovka HPP\#2 and the further development of small hydropower;

$-a_{4}$ is the second stage of reconstruction of the HPPs of the Dniprovsky and Dnistrovsky cascades and the building of the Upper Dnistrovskyi cascade of HPPs;

$-a_{5}$ is the second stage of reconstruction of the HPPs of the Dniprovsky and Dnistrovsky cascades, the construction of the Upper Dnistrovskyi cascade of HPPs and the further development of small hydropower;

$-a_{6}$ is the second stage of reconstruction of the HPPs of the Dniprovsky and Dnistrovsky cascades, the construction of the Kakhovka HPP\#2 and the construction of the Upper Dnistrovskyi cascade of HPPs;

$-a_{7}$ is the second stage of reconstruction of the HPPs of the Dniprovsky and Dnistrovsky cascades, the construction of the Kakhovka HPP\#2 and the Upper Dnistrovskyi cascade of HPPs and the development of small hydropower.

Table 5 - The characteristics of alternatives $a_{0} \div a_{7}$

\begin{tabular}{|c|c|c|c|c|c|}
\hline \multirow{2}{*}{ Alternatives } & \multicolumn{5}{|c|}{ Characteristics } \\
\cline { 2 - 6 } & $N, \mathrm{MW}$ & $E, \mathrm{MW} \cdot \mathrm{h}$ & $C, 10^{9}, \mathrm{hrs}$ & $C_{E}$ & $N_{\text {reg }}, \mathrm{MW}$ \\
\hline$a_{0}$ & 307 & 330 & 22.33 & 330 & 276.3 \\
\hline$a_{1}$ & 395 & 450 & 22.33 & 930 & 293.9 \\
\hline$a_{2}$ & 557 & 374 & 35.8 & 374 & 513.8 \\
\hline$a_{3}$ & 645 & 494 & 35.8 & 974 & 531.4 \\
\hline$a_{4}$ & 697 & 1040 & 54.23 & 1040 & 529.8 \\
\hline$a_{5}$ & 785 & 1160 & 54.23 & 1640 & 547.4 \\
\hline$a_{6}$ & 947 & 1084 & 67.7 & 1084 & 767.3 \\
\hline$a_{7}$ & 1035 & 1204 & 67.7 & 1684 & 784.9 \\
\hline
\end{tabular}

As characteristics, from which the components of the risk $l$ were formed, costs of construction (or reconstruction) $C$ of HPPs and averaged (weighted) expected costs of power buying $C_{E}$ depending on alternatives $a_{0} \div a_{7}$ were considered. Costs $C_{E}$ were determined according to formula: 


$$
\begin{gathered}
\sim 41 \sim \\
C_{E}=\sum_{k=1} E_{k} \cdot v_{k},
\end{gathered}
$$

where $E_{k}$ is the total quantity and $v_{k}$ is score value of tariff of the unit of electricity produced by the source of hydrogeneration with the index $k$.

For our research, if electricity is produced at large HPPs score value of tariff $v_{k}$ is equal 1 . If electricity is produced at small HPPs, let $v_{k}$ will be 5 .

As characteristics, from which the components of the risk of unused possibilities $g$ were formed, the power capacities $N_{\text {reg }}$, which can be used in adjusting the load schedule in the CES of the country, and power generation $E$ depending on alternatives $a_{0} \div a_{7}$ were considered. The corresponding power capacities $N_{\text {reg }}$ were determined according to the formula:

$$
N_{r e g}=\sum_{k=1} N_{k} \cdot c_{k}
$$

where $N_{k}$ is the installed capacity and $c_{k}$ is the reliability coefficient concerning regulation possibilities in the framework of the CES depending on the source of hydrogeneration with the index $k$, respectively.

For our research the following values $c_{k}$ are taken: the HPPs of the Dniprovsky and Dnistrovsky cascades, the reliability coefficient $c_{k}=0.9$; the Kakhovka HPP\#2, $c_{k}=0.95$; the Upper Dnistrovskyi cascade of HPPs, $c_{k}=0.65$; in the case of small hydropower, $c_{k}=0.2$.

The results of numerical assessment of risk components of the considered alternatives $a_{0} \div a_{7}$ are given in Table 6 . The results of their pairwise comparison in accordance with the rule (1) are given in Table 7 .

Table 6 - Results of numerical assessment of risk components of the alternatives $a_{0} \div a_{7}$

\begin{tabular}{|c|c|c|c|c|c|c|}
\hline \multirow{2}{*}{ Alternatives } & \multicolumn{3}{|c|}{ Systemic risk } & \multicolumn{3}{c|}{ Risk of unused possibilities } \\
\cline { 2 - 7 } & $C$ & $C_{E}$ & $l$ & $N_{\text {reg }}$ & $E$ & $g$ \\
\hline$a_{0}$ & 0.00 & 0.00 & 0.00 & 0.00 & 0.00 & 0.00 \\
\hline$a_{1}$ & 0.00 & 6.36 & 6.36 & 0.59 & 2.40 & 2.99 \\
\hline$a_{2}$ & 4.26 & 0.77 & 5.02 & 5.94 & 0.97 & 6.91 \\
\hline$a_{3}$ & 4.26 & 6.64 & 10.90 & 6.26 & 3.12 & 9.38 \\
\hline$a_{4}$ & 8.00 & 7.04 & 15.04 & 6.24 & 8.87 & 15.10 \\
\hline$a_{5}$ & 8.00 & 9.84 & 17.84 & 6.55 & 9.71 & 16.26 \\
\hline$a_{6}$ & 10.00 & 7.30 & 17.30 & 9.78 & 9.19 & 18.97 \\
\hline$a_{7}$ & 10.00 & 10.00 & 20.00 & 10.00 & 10.00 & 20.00 \\
\hline
\end{tabular}


Table 7 - Decision table for pairwise comparison of the considered alternatives

\begin{tabular}{|c|c|c|c|c|c|c|c|c|}
\hline$a_{i} / a_{j}$ & $a_{0}$ & $a_{1}$ & $a_{2}$ & $a_{3}$ & $a_{4}$ & $a_{5}$ & $a_{6}$ & $a_{7}$ \\
\hline$a_{0}$ & - & $\mathbf{2 . 9 9}$ & $\mathbf{6 . 9 1}$ & 9.38 & 15.10 & 16.26 & 18.97 & 20.00 \\
\hline$a_{1}$ & $\mathbf{6 . 3 6}$ & - & $\mathbf{1 3 . 2 7}$ & 9.97 & 21.46 & 22.62 & 25.33 & 26.36 \\
\hline$a_{2}$ & $\mathbf{5 . 0 2}$ & $\mathbf{8 . 0 1}$ & - & $\mathbf{1 4 . 4 0}$ & $\mathbf{2 0 . 1 3}$ & $\mathbf{2 1 . 2 8}$ & $\mathbf{2 4 . 0 0}$ & $\mathbf{2 5 . 0 2}$ \\
\hline$a_{3}$ & 10.90 & 13.88 & $\mathbf{1 7 . 8 0}$ & - & 26.00 & 27.16 & 29.87 & 30.90 \\
\hline$a_{4}$ & 15.04 & 18.03 & $\mathbf{2 1 . 9 5}$ & 24.42 & - & 31.30 & 34.01 & 35.04 \\
\hline$a_{5}$ & 17.84 & 20.83 & $\mathbf{2 4 . 7 5}$ & 27.22 & 32.94 & - & 36.81 & 37.84 \\
\hline$a_{6}$ & 17.30 & 20.28 & $\mathbf{2 4 . 2 1}$ & 26.68 & 32.40 & 33.56 & - & 37.30 \\
\hline$a_{7}$ & 20.00 & 22.99 & $\mathbf{2 6 . 9 1}$ & 29.38 & 35.10 & 36.26 & 38.97 & - \\
\hline
\end{tabular}

So, the best alternative is $a_{2}$. This alternative is burdened with the lowest risk when pairwise comparison with any other alternative among the considered alternatives $a_{i}, i=\overline{0,7}$.

\section{Conclusions}

The results of our research show that the best alternative to build new hydropower plants in the country among the considered alternatives the alternative $a_{2}$ is. This is the second stage of reconstruction of the HPPs of the Dniprovsky and Dnistrovsky cascades and also the construction of the Kakhovka HPP\#2. This alternative should be considered the most feasible to improve situation in the domestic hydropower without significant risks.

As well as, it should be noted that alternatives, which provide for the further development of small hydropower in the country, are worse than alternatives which neglect its development. It may indicate that decision to develop small hydropower in the country under the current conditions and thanks to the "green tariff" is questionable and ungrounded.

\section{REFERENCES}

1. Відновлювана енергетика та енергоефективність у XXI столітті: матеріали XIX міжнародної науково-практичної конференції (Київ, 26-28 вересня 2018 р.). 674 с.

2. Відновлювана енергетика та енергоефективність у XXI столітті: матеріали XX міжнародної науково-практичної конференції (Київ, 15-16 травня 2019 р.). Київ : Інтерсервіс, 2019. 952 с.

3. Інформація щодо потужності та обсягів виробництва електроенергії об'єктами відновлюваної електроенергетики, які працюють за «зеленим» тарифом (станом на 01.01.2017). 5 c. URL: http://saee.gov.ua/sites/default/ files/Info\%20elektry\%60ka\%20VDE.pdf.

4. Потужності відновлюваної електроенергетики у 2017 році зросли у два рази. URL: https://uprom.info/news/energy/potuzhnosti-vidnovlyuvanoyi-elektroenergetiki-u-2017rotsi-zrosli-u-dva-razi/.

5. Інформація щодо потужності та обсягів виробництва електроенергії об'єктами відновлюваної електроенергетики, яким встановлено «зелений» тариф (станом на 30.06.2018). 4 c. URL: http://saee.gov.ua/sites/default/ files/RE_1_half_2018.pdf. 
6. Інформація щодо потужності та обсягів виробництва електроенергії об'єктами відновлюваної електроенергетики, яким встановлено «зелений» тариф (станом на 30.09.2018). 4 c. URL: http://saee.gov.ua/sites/default/ files/VDE.pdf.

7. Програма розвитку гідроенергетики на період до 2026 року : Схвалено розпорядженням КМ України від 13.07. 2016 p. № 552-p. URL: http://zakon2.rada.gov.ua/laws/show/552-2016-\%D1\%80\#n7.

8. Шидловський А.К., Поташник С.І., Федоренко Г.М. Надійні гідроелектростанції гарант технологічної безпеки та ефективної експлуатації АЕС та ТЕС. Гідроенергетика України. 2005. № 1. С. 8-11.

9. Розвиток теплоенергетики та гідроенергетики / Є.Т. Базеєв, Б.Д. Білека, Є.П. Васильєв та ін.; Наук. ред.. В.М. Клименко, Ю.О. Ландау, І.Я. Сігал. 2013. 399 с. URL: http://energetika.in.ua/ua/books/book-3/part-2/section-2/2-8.

10.Власюк Ю.С., Стефанишин Д.В. Про проблеми та перспективи малої гідроенергетики в Україні. Математичне моделювання в економіці. №1. 2018. C. $126-138$.

11. Стефанишин Д.В., Власюк Ю.С. До питання порівняльного аналізу водноенергетичних характеристик малих і великих гідроелектростанцій України у складі гідровузлів з водосховищами. Математичне моделювання в економіці. №2. 2018. С. 71-83.

12. «Зелений» тариф для міні-ГЕС сприяє знищенню українських річок, - експерт WWF. URL: https://zik.ua/news/2016/09/12/zelenyy_taryf_dlya_miniges_spryyaie_ znyshchennyu_ukrainskyh_richok_ekspert_856872.

13. Stefanyshyn D. On peculiarities of hydropower development in the world and in Ukraine. Екологічна безпека та природокористування. Зб. наук. праць. Вип. 25 (№ 1). Київ: КНУБА, ІТГІП НАНУ. 2018. С. 12-23.

14. Стефанишин Д.В. Проблеми та перспективи гідроакумуляції в контексті раціонального природокористування та екологізації гідроенергетики в Україні. Математичне моделювання в економіці. №3(12). 2018. С. 101-113.

15. Ivashintsov D.A., Stefanishin D.V., Veksler A.B. Ecological and sociodemographic consequences of hydrotechnical construction (Problems of safety and risk). Power Technology and Engineering. Vol. 27. Issue 12. December, 1993. P.P. 685-691. DOI: 10.1007/BF01545709.

16. Environmental experience gained from reservoirs in operation. Trans. of the 18-th Int. Congress on Large Dams. Vol. 2. Q.69. Durban - South Africa, November, 1994. 780 p.

17. Стефанишина-Гаврилюк Ю.Д., Стефанишин Д.В. Прийняття рішень у природокористуванні 3 урахуванням ризику невикористаних можливостей на підставі попарного порівняння альтернатив. Системні дослідження та інформаційні технології. 2016. №3. С. 51-62.

18. Стефанишин Д.В. Про перспективи гідроенергетики в Україні та вибір варіанту розвитку Дніпровського каскаду з врахуванням ризику. Гідроенергетика України. 2010. №3. С. 5-11.

19. Стефанишин Д.В. Обгрунтування оптимального сценарію введення нових агрегатів на гідроакумулюючих електростанціях в Україні 3 врахуванням ризику. Гідроенергетика України. №3-4. 2018. С. 24-29.

\section{REFERENCES (TRANSLATED AND TRANSLITERATED)}

1. Renewable Energy and Energy Efficiency in the 21st Century. (2018). Materials of the XIX International Scientific and Practical Conference (Kyiv, September 26-28, 2018), 674 p. (in Ukrainian).

2. Renewable Energy and Energy Efficiency in the 21st Century. (2019). Materials of the XX International Scientific and Practical Conference (Kyiv, May 15-16, 2019). Kyiv, Interservice, 952 p. (in Ukrainian). 
3. Information on power and volumes of electricity production by renewable energy companies operating under the "green" tariff (as of 01.01.2017). 5 p. Retrieved from http://saee.gov.ua/sites/default/files/Info\%20elektry\%60ka\% 20VDE.pdf. (in Ukrainian).

4. The power of renewable energy in 2017 has doubled. Retrieved from https://uprom.info/news/energy/potuzhnosti-vidnovlyuvanoyi-elektroenergetiki-u-2017rotsi-zrosli-u-dva-razi/. (in Ukrainian).

5. Information on power and volumes of electricity produced by renewable energy objects, which have a "green" tariff (as of June 30, 2018). 4 p. Retrieved from http://saee.gov.ua/sites/default/files/RE_1_half_2018.pdf. (in Ukrainian).

6. Information on power and volumes of electricity produced by renewable energy objects, which have a "green" tariff (as of September 30, 2018). 4 p. Retrieved from http://saee.gov.ua/sites/default/files/VDE.pdf. (in Ukrainian).

7. Hydropower development program for the period up to 2026. Approved by the order of the Cabinet of Ministers of Ukraine from 13.07. 2016 № 552-r. Retrieved from http://zakon2.rada.gov.ua/laws/show/552-2016-\%D1\%80\#n7. (in Ukrainian).

8. Shidlovsky, A. K., Potashnik, S. I., Fedorenko, G. M. (2005). Reliable hydropower plants are the guarantor of technological safety and efficient operation of NPPs and TPPs. Hydropower of Ukraine, № 1, 8-11. (in Ukrainian).

9. Development of heat power engineering and hydropower. (2013). Baseev, Ye. T., Bileka, B. D., Vasiliev, Ye. P., et al .; Science ed. Klymenko, V. M., Landau, Yu. O., Sigal, I. Ya. 399 p. Retrieved from http://energetika.in.ua/ua/books/book-3/part-2/section-2/2-8. (in Ukrainian).

10. Vlasyuk, Yu. S., Stefanyshyn, D. V. (2018). On problems and prospects of small hydropower engineering in Ukraine. Mathematical Modeling in Economy, №1, 2018, 126138. (in Ukrainian).

11. Stefanyshyn, D. V., Vlasyuk, Yu. S. (2018). To the issue of comparative analysis of waterenergy characteristics of small and large hydroelectric power plants of Ukraine being parts of waterworks with reservoirs. Mathematical Modeling in Economy, №2, 71-83. (in Ukrainian).

12. "Green" tariff for mini-HPP promotes the destruction of Ukrainian rivers, - WWF expert. Retrieved from https://zik.ua/news/2016/09/12/zelenyy_taryf_dlya_miniges_spryyaie_ znyshchennyu_ukrainskyh_richok_ekspert_856872. (in Ukrainian).

13. Stefanyshyn, D. V. (2018). On peculiarities of hydropower development in the world and in Ukraine. Environmental safety and natural resources. Issue 25 (№ 1), Kyiv, KNUBA, ITGIP of NASU, 12-23.

14. Stefanyshyn, D. V. (2018). Problems and prospects of hydro-accumulation in the context of rational nature management and ecologization of hydropower in Ukraine. Mathematical Modeling in Economy, №3 (12), 101-113. (in Ukrainian).

15. Ivashintsov D.A., Stefanishin D.V., Veksler A. B. (1993). Ecological and sociodemographic consequences of hydrotechnical construction (Problems of safety and risk). Power Technology and Engineering, Vol. 27, Issue 12, December, 685-691. DOI: 10.1007/BF01545709.

16. Environmental experience gained from reservoirs in operation. (1994). Trans. of the 18-th Int. Congress on Large Dams. Vol. 2. Q.69. Durban - South Africa, November, 780 p.

17. Stefanyshyna-Gavryliuk, Yu. D., Stefanyshyn, D. V. (2016). Decision-making in natural resources use taking into account the risk of lost opportunities based on pairwise comparison of alternatives. System Research and Information Technologies, №3, 51-62. (in Ukrainian).

18. Stefanyshyn, D. V. (2010). About the prospects of hydropower in Ukraine and the choice of the variant of development of the Dnipro cascade taking into account the risk. Hydropower of Ukraine, №3, 5-11. (in Ukrainian).

19. Stefanyshyn, D. V. (2018). Grounding the optimal scenario for the introduction of new aggregates at the hydroelectric power plants in Ukraine taking into account the risk. Hydropower of Ukraine, №3-4, 24-29. (in Ukrainian). 


\section{Д.В. Стефанишин}

\section{АНАЛІЗ ДОЦІЛЬНОСТІ БУДІВНИЦТВА НОВИХ ГЕС В УКРАЇНІ З УРАХУВАННЯМ РИЗИКУ НЕВИКОРИСТАНИХ МОЖЛИВОСТЕЙ}

Анотація. У статті представлено результати аналізу доцільності будівництва нових гідроелектростанцій в Україні відповідно до Програми розвитку гідроенергетики України до 2026 року, затвердженої Урядом у 2016 році. Зокрема, аналізуються перспективні плани щодо розширення Каховської ГЕС з побудовою Каховської ГЕС-2, будівництва каскаду з шести нових гідроелектростанцій на річці Дністер та розвиток малої гідроенергетики в країні. Аналіз базується на попарному порівнянні альтернатив за критерієм мінімального сумарного ризику з урахуванням ризику невикористаних можливостей. Складові сумарних ризиків альтернатив оцінюються в безрозмірних одиницях, якими описуються водноенергетичні і експлуатаційні характеристики та затрати на введення нових гідроагрегатів.

Ключові слова: сукупний ризик; альтернатива; аналіз доцільності; прийняття рішень; гідроенергетика; гідроелектростанції; оптимізація; попарне порівняння; відновлювана енергетика; ризик невикористаних можливостей

\section{Стефанишин Дмитро Володимирович}

доктор технічних наук, провідний науковий співробітник Інституту телекомунікацій і глобального інформаційного простору НАНУ, професор кафедри гідротехнічного будівництва та гідравліки Національного університету водного господарства та природокористування (НУВГП)

Адреса робоча: 33028 Україна, м. Рівне, вул. Соборна, 11

e-mail:d.v.stefanyshyn@nuwm.edu.ua

ORCID: https://orcid.org/0000-0002-7620-1613 